\title{
Production and Characterization of
}

\section{Alkaline Protease from a High Yielding and Moderately Halophilic Strain of SD1 1 Marine Bacteria}

\author{
Hongxia Cui, ${ }^{1,2}$ Liping Wang, ${ }^{3}$ and Yang Yu ${ }^{4}$ \\ ${ }^{1}$ College of Environmental and Chemical Engineering, Yanshan University, Qinhuangdao, Hebei 066004, China \\ ${ }^{2}$ Hebei Province Key Laboratory of Applied Chemistry, Qinhuangdao, Hebei 066004, China \\ ${ }^{3}$ Sansom Institute for Health Research, School of Pharmacy and Medical Sciences, University of South Australia, \\ Adelaide, SA 5001, Australia \\ ${ }^{4}$ Flinders Centre for Nanoscale Science \& Technology, School of Computer Science, Engineering and Mathematics, \\ Flinders University, Adelaide, SA 5042, Australia \\ Correspondence should be addressed to Hongxia Cui; hxcui@ysu.edu.cn
}

Received 16 December 2014; Revised 5 May 2015; Accepted 6 May 2015

Academic Editor: Murat Senturk

Copyright @ 2015 Hongxia Cui et al. This is an open access article distributed under the Creative Commons Attribution License, which permits unrestricted use, distribution, and reproduction in any medium, provided the original work is properly cited.

\begin{abstract}
A marine bacterium SD11, which was isolated from sea muds (Geziwo Qinhuangdao Sea area, China), was used to produce thermostable alkaline serine nonmetal protease in the skim milk agar plate medium with $10 \% \mathrm{NaCl}$. The optimal temperature about the manufacture of the extracellular protease was $\sim 60^{\circ} \mathrm{C}$. The crude enzyme was stable at $20-50^{\circ} \mathrm{C}$. The activity was retained to $60 \%$ and $45 \%$ after heating for $1 \mathrm{~h}$ at 60 and $70^{\circ} \mathrm{C}$, respectively. The protease was highly active in a wide $\mathrm{pH}$ scope (8.0-10.0) and maximum protease activity exhibited at $\mathrm{pH}$ 10.0. The activity was restrained by phenylmethylsulfonyl fluoride (PMSF) but mildly increased $(\sim 107 \%)$ in the presence of ethylenediaminetetraacetic acid (EDTA), indicating that the production contains serine-protease(s) and nonmetal protease(s). Moreover, the crude alkaline protease was active with the $5 \mathrm{mM} \mathrm{Ca}{ }^{2+}, \mathrm{Mn}^{2+}, \mathrm{Zn}^{2+}, \mathrm{Cu}^{2+}$, $\mathrm{Na}^{+}$, and $\mathrm{K}^{+}$that existed separately. In addition, the protease showed superduper stability when exposed to an anionic surfactant (5 mM SDS), an oxidizing agent $\left(1 \% \mathrm{H}_{2} \mathrm{O}_{2}\right)$, and several organic solvents (methanol, isopropanol, and acetone). These results suggest that the marine bacterium SD11 is significant in the industry from the prospects of its ability to produce thermally stable alkaline protease.
\end{abstract}

\section{Introduction}

Protease and other carbohydrate-hydrolyzing enzymes are the most important among industrial enzymes and have been researched widely. Proteases constitute one of the third largest groups of enzymes in industry $[1,2]$, with two-thirds of the proteases produced by microorganisms commercially [3]. They are used in all kinds of industrial situations such as pharmaceuticals, drug manufacturing, detergents, surface cleaning formulations, waste treatment, silver recovery, digestive supplements, agrochemical additives, and diagnostic reagents [4-6]. It is said that $40 \%$ of the enzymes used today are produced by microorganisms including bacteria, molds, and yeasts [7]. The growth rate of microorganisms is very quick. A large number of microorganisms may be accumulated in a relatively short time through cultivation methods, while they can be used to generate a sufficient, regular supply of the expected product, such as proteases. Among them, bacteria are the most primary species of alkaline protease generators and Bacillus genus is the most dominant source $[5,8-10]$. Proteases from microorganisms especially from Bacillus sp. are the most extensively developed industrial proteases that have been used mainly in detergent formulations $[11,12]$.

Recently, the enzymes produced by moderately halophilic microorganisms have gained significant attention [13]. Unlike other enzymes that can be inhibited by the concentrated salt solutions, they have optimal activities at high salinity conditions and, therefore, could be used in much severe 
industrial procedures [14]. Certain species of halophilic microorganisms (such as Pseudoalteromonas sp. Strain CP76 [15], Bacillus clausii [16], and other halophilic isolates) have been commonly used for protease production [17].

The property of proteases used in abstergents relies on several indexes, such as ionic strength, $\mathrm{pH}$, composition of the abstergent, washing temperature/procedure, and hardness of water. One of the most important features, for the enzymes used in detergents, is their stability, and different methods have been applied to better the washing performance and enzymatic stability against bleaching agents [18]. Nature is a good source for these enzymes, and current studies have been focusing on the proteolytic enzymes (such as hot spring microorganisms and terrestrial Bacilli [19-21]), and little attention was being given to marine microorganisms.

The oceans covering $71 \%$ of the planet possess an important bioresource for microorganisms. The metabolism and physiologic features of marine microorganisms were found to be different from that of terrestrial microorganisms [22]. Isolation and screening of strains from marine environment are hoped to supply new strains using the manufacture of stable and active proteases in highly alkaline environments with the presence of chemical reagents from detergents. In this paper, a high alkaline protease yielding, moderately halophilic bacterium SD11 was screened and isolated from marine bacteria. The effects of the activities and stabilities of the protease by $\mathrm{pH}$, temperature, metal ions, organic solvents, and detergents were also studied.

In the paper, the screening of marine bacteria was reported. The moderately halophilic bacterium SD11 had the high ability to produce alkaline protease. The biochemical characterization of the crude enzyme was investigated too.

\section{Experiments}

2.1. Isolation and Screening of Alkaline Proteases Producing Strains. In order to isolate the protease-producing bacteria, the samples were gathered from sea muds in the Geziwo Qinhuangdao Sea area and were diluted with sterile sea water. Then the diluents were spread onto skimmed milk agar plates containing beef extract $(3 \mathrm{~g} / \mathrm{L})$, peptone $(10 \mathrm{~g} / \mathrm{L})$, $\mathrm{NaCl}(10 \mathrm{~g} / \mathrm{L})$, skimmed milk powder $(10 \mathrm{~g} / \mathrm{L})$, and $18 \mathrm{~g} / \mathrm{L}$ agar, with $\mathrm{pH}$ adjusted to 8.5. Plates were incubated $24 \mathrm{~h}$ at $37^{\circ} \mathrm{C}$. It was confirmed that the screened bacteria could produce proteinase when the clear proteolytic zone was found around the colonies [23], which were chosen for the purification the subsequent research. One loop of the cells of the purified strains was inoculated with $20 \mathrm{~mL}$ of protease production medium consisting of beef extract $(3 \mathrm{~g} / \mathrm{L})$, peptone $(10 \mathrm{~g} / \mathrm{L})$, and $\mathrm{NaCl}(7 \mathrm{~g} / \mathrm{L})$, with $\mathrm{pH}$ 8.5. The medium was prepared with sea water in $100 \mathrm{~mL}$ flask and aerobically cultivated by shaking at $150 \mathrm{rpm}$ and $37^{\circ} \mathrm{C}$ for $24 \mathrm{~h}$. Strain SD11 was found to generate maximum enzyme activity in the fluid medium. So it was used to investigate the characterization of protease. The organism was stored at $4^{\circ} \mathrm{C}$.
2.2. Fermentations and Crude Enzyme Preparation. SD11 strain was fermented in protease production medium consisting of beef extract $(3 \mathrm{~g} / \mathrm{L})$, peptone $(10 \mathrm{~g} / \mathrm{L})$, and $\mathrm{NaCl}(7 \mathrm{~g} / \mathrm{L})$, with $\mathrm{pH}$ 8.5. The media were autoclaved for $20 \mathrm{~min}$ at $121^{\circ} \mathrm{C}$. Fermentation processes were completed on a rotary shaker at $37^{\circ} \mathrm{C}$ for $24 \mathrm{~h}$ at $150 \mathrm{rpm}$, with $50 \mathrm{~mL}$ working volume in $250 \mathrm{~mL}$ triangular flasks.

The centrifugal machine was used to separate the biomass produced at $4^{\circ} \mathrm{C}$ for $10 \mathrm{~min}$ at $10000 \mathrm{rpm}$. The supernatant was added different concentrations ammonium sulfate to reach different saturation levels $(0-80 \%)$ for precipitation. The fraction of precipitation was dissolved in phosphate buffer (PBS, pH 7.4). It was dialyzed against the same buffer. Then the contents of protein and activity of enzyme were determined. The specific activity of the protease was showed as enzyme activity per mg protein [24].

2.3. Denatured Polyacrylamide Gel Electrophoresis. The molecular weight of the protease was tested by SDS-PAGE with stacking gel (4\%) and resolving gel (10\%) as introduced by Laemmli [25] with slight modification. The enzymatic molecular weight was determined using a calibration molecular weight kit with markers containing of $14.4 \mathrm{kD}$, $18.4 \mathrm{kD}, 25.0 \mathrm{kD}, 35.0 \mathrm{kD}, 45.0 \mathrm{kD}, 66.2 \mathrm{kD}$, and $116 \mathrm{kD}$. Coomassie Brilliant Blue R-250 was used to stain and visualize the bands of the protein.

2.4. Determination of Enzyme Activity. The activity of protease (caseinolytic) was assayed by a modification method of Kunitz [26]. The reaction system $(0.6 \mathrm{~mL})$ consisted of $150 \mu \mathrm{L}$ of $1 \%$ Hammerstein grade casein in $200 \mathrm{mM}$ glycine- $\mathrm{NaOH}$ buffer ( $\mathrm{pH} 10.0$ ) and $150 \mu \mathrm{L}$ of enzyme solution or cultivated supernatant. The reaction was beginning with adding an enzyme solution at $40^{\circ} \mathrm{C}$. The reaction was terminated by adding $0.4 \mathrm{M}$ trichloroacetic acid (TCA, $300 \mu \mathrm{L}$ ) after the reaction was sustained for $15 \mathrm{~min}$. The reaction system was sustained on ice for another $10 \mathrm{~min}$. Then it was centrifuged at $4^{\circ} \mathrm{C}$ for $10 \mathrm{~min}$ at $10000 \mathrm{rpm} .0 .3 \mathrm{~mL}$ of supernatant, the hybrid with $1.5 \mathrm{~mL}$ of a $0.4 \mathrm{M} \mathrm{Na}_{2} \mathrm{CO}_{3}$ solution in $2.1 \mathrm{~mL}$ distilled water, and $0.3 \mathrm{~mL}$ of Folin-Ciocalteu reagent were incubated for $20 \mathrm{~min}$ at $40^{\circ} \mathrm{C}$. The amount of L-tyrosine from digested casein was measured by determining the absorbance by using a UV-vis spectrophotometer at $680 \mathrm{~nm}$ in the supernatant. The standard curve was done using L-tyrosine as a standard substance. One unit of enzyme activity was defined as the quantity of protease that liberates $1 \mu \mathrm{g} / \mathrm{mL}$ of tyrosine per min [27].

2.5. Determination of Protein. The method described by Bradford was used to measure the protein concentration [28]. The bovine serum albumin was selected to as a standard. The absorbance was determined at $280 \mathrm{~nm}$.

\subsection{Biochemical Characteristics}

2.6.1. Effect of Crude Alkaline Protease Activity and Stability by $\mathrm{pH}$. The range of $\mathrm{pH} 7.0-13.0$ was selected to observe the optimal $\mathrm{pH}$ of the preliminarily purified protease at $40^{\circ} \mathrm{C}$. The casein $1 \%(\mathrm{w} / \mathrm{v})$ was used as a substrate. The influence of $\mathrm{pH}$ 
on protease stability was also determined. The protease was incubated in advance in different $\mathrm{pH}$ buffers of 7.0-12.0 for $1 \mathrm{~h}$ at $40^{\circ} \mathrm{C}$. The incubations were taken at the suitable time to measure the residual activity at $40^{\circ} \mathrm{C}$ and $\mathrm{pH}$ 10.0. $200 \mathrm{mM}$ sodium phosphate buffer was used for $\mathrm{pH}$ 7.0-8.0. $200 \mathrm{mM}$ glycine- $\mathrm{NaOH}$ buffer was used for 9.0-13.0.

\subsubsection{Effect of Crude Alkaline Protease Activity and Stability} by Temperature. The influence of alkaline protease activity by temperature was investigated from 20 to $70^{\circ} \mathrm{C}$ in $\mathrm{pH} 10.0$ for 20 min with casein substrate. Thermostability of the protease was also investigated. The preliminarily purified protease was incubated in advance for $1 \mathrm{~h}$ at different temperatures $(20,30$, $40,50,60$, and $70^{\circ} \mathrm{C}$ ). The incubations were taken at suitable time to examine the residual enzyme activity under normal conditions. The unheated protease was regarded as 100\% [29].

2.6.3. Effects of Crude Alkaline Protease Activity by Inhibitors and Metal Ions. The influences of protease activity by all kinds of metal ions $(5 \mathrm{mM})$ were examined by adding the divalent $\left(\mathrm{Zn}^{2+}, \mathrm{Mn}^{2+}, \mathrm{Ca}^{2+}\right.$, or $\left.\mathrm{Cu}^{2+}\right)$ metal ions and monovalent $\left(\mathrm{Na}^{+}\right.$and $\left.\mathrm{K}^{+}\right)$in the reaction system. The protease activity was regarded as $100 \%$ when there were no any metallic ions in the reaction system.

The effects of $5 \mathrm{mM}$ EDTA or PMSF (phenylmethylsulfonyl fluoride) on the activity of protease were investigated too. The preliminarily purified protease was incubated in advance with EDTA or PMSF at $40^{\circ} \mathrm{C}$ for $20 \mathrm{~min}$. The incubations were taken at the suitable time to determine the residual enzyme activity under normal conditions. The reaction mixture was regarded as control (100\%) without EDTA or PMSF.

2.6.4. Effect of Crude Alkaline Protease Activity by Organic Solvents and Detergents. The influence of crude enzyme activity by various organic solvents was examined. The crude enzyme was incubated in advance in $100 \mathrm{mM}$ glycine- $\mathrm{NaOH}$ buffer system ( $\mathrm{pH} 10.0)$ with $25 \%(\mathrm{v} / \mathrm{v})$ of several organic solvents (isopropanol, methanol, and acetone) and shaken at $150 \mathrm{rpm}$ for $20 \mathrm{~min}$ at $40^{\circ} \mathrm{C}$. The incubations were taken at the suitable time to determine the residual activity under normal conditions. The activity of the protease was regarded as controls without any organic solvents.

The effects of $5 \mathrm{mM}$ surfactant SDS and $1 \%$ (v/v) oxidizing agent $\mathrm{H}_{2} \mathrm{O}_{2}$ on protease activity were investigated with incubating the crude protease in advance at $40^{\circ} \mathrm{C}$ for $20 \mathrm{~min}$. The incubations were taken at the suitable time to determine the residual enzyme activity under normal conditions. The activity of the protease was regarded as $100 \%$ without SDS or $\mathrm{H}_{2} \mathrm{O}_{2}$.

\section{Results and Discussions}

3.1. Isolation and Screening of Alkaline Proteases Producing Bacteria. In this study, total 116 bacteria were obtained from sea muds obtained, but only 14 strains could form a clear zone of hydrolysis of skimmed milk powder on the agar plate. This finding is similar to the results reported by Visôtto et al. [30]
TABLE 1: The diameter of colony and hydrolyzed zone.

\begin{tabular}{lccc}
\hline Strains & $\begin{array}{c}\text { Diameter of } \\
\text { colony }(D)\end{array}$ & $\begin{array}{c}\text { Diameter of } \\
\text { hydrolyzed zone } \\
(d)\end{array}$ & $d / D$ \\
\hline SD7 & 1.88 & 2.84 & 1.51 \\
SD8 & 1.64 & 2.78 & 1.70 \\
SD9 & 1.83 & 2.95 & 1.61 \\
SD10 & 1.77 & 3.2 & 1.81 \\
SD11 & 2.31 & 4.05 & 1.75 \\
SDL9 & 2.15 & 3.4 & 1.58 \\
\hline
\end{tabular}

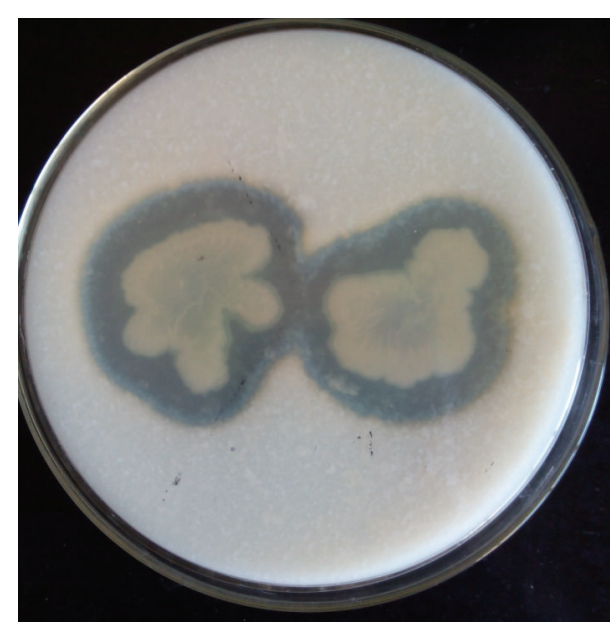

FIGURE 1: Screening of strain SD11 for protease activity. Isolate was streaked on the agar plate containing skimmed milk powder and $10 \%$ $\mathrm{NaCl}$, incubated for $24 \mathrm{~h}$ at $37^{\circ} \mathrm{C}$. The clear hydrolysis zone indicated the hydrolysis of skimmed milk.

where they found several bacterial strains including B. subtilis with proteolytic activity from the caterpillar gut on calcium caseinate agar. Among them, one strain named SD11 provided very clear hydrolysis zones around the bacterial colonies on the milk agar plates with $10 \% \mathrm{NaCl}$ that is indicating it produces dominant amounts of protease (Figure 1). The ratio of the clear hydrolysis zone diameter and that of the bacterial colony on skimmed milk agar plate, six isolates SD7, SD8, SD9, SD10, SD11, and SDL9, exhibited the highest ratio $(>1.5)$, which were shown in Table 1. And then, they were investigated for the production of protease in liquid medium. In Figure 2, the results indicated that protease activity of strain SD11 was the highest $171.9 \mathrm{U} / \mathrm{mL}$ in a nonoptimized medium after it was incubated for $24 \mathrm{~h}$. Therefore, strain SD11 was selected for all subsequent researches.

3.2. Alkaline Protease Partial Purification. The purification process of protease from strain SD11 was illustrated in Table 2. The supernatant contained a total activity of $1970.70 \mathrm{U}$ after growth of strain SD11 for $24 \mathrm{~h}$ and a specific activity of $182.47 \mathrm{U} / \mathrm{mg}$ protein. It was regarded as the control (100\%). And then, the supernatant was added with ammonium sulfate for precipitation under $0-80 \%$ saturation. The maximum activity of protease was obtained with $60 \%$ ammonium 
TABle 2: Purification of protease from strain SD11.

\begin{tabular}{|c|c|c|c|c|c|}
\hline Purification step & $\begin{array}{c}\text { Total activity } \\
\text { (U) }\end{array}$ & $\begin{array}{l}\text { Total protein } \\
(\mathrm{mg})\end{array}$ & $\begin{array}{l}\text { Specific activity } \\
\text { (U/mg protein) }\end{array}$ & Yield (\%) & $\begin{array}{l}\text { Purification } \\
\text { (fold) }\end{array}$ \\
\hline $\begin{array}{l}\text { Culture } \\
\text { supernatant }\end{array}$ & 1970.70 & 10.80 & 182.47 & 100 & 1 \\
\hline $\begin{array}{l}\text { Ammonium } \\
\text { sulphate } \\
\text { precipitation }(60 \%)\end{array}$ & 1340.18 & 3.10 & 432.32 & 68 & 2.37 \\
\hline
\end{tabular}

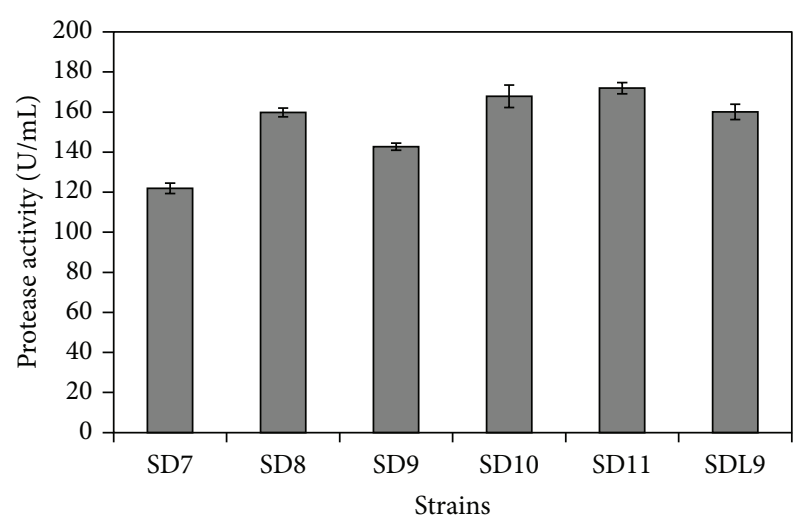

FIGURE 2: Protease activity of culture supernatant of different strains.

sulfate saturation. The total activity of protease was $1340.18 \mathrm{U}$, and purification fold was 2.37. The specific activity was increased to $432.32 \mathrm{U} / \mathrm{mg}$ protein with a yield of $68 \%$. The production of ammonium sulfate precipitation was conducted by SDS-PAGE electrophoresis method (Figure 3 ). The results showed that one clear band existed, and the molecular weight of the band of the protease was about $45 \mathrm{kD}$. Then the crude protease of strain SD11 was used to study the characteristics.

\subsection{Effect of Activity and Stability of the Crude Alkaline} Protease by $\mathrm{pH}$. The influence of protease activity by $\mathrm{pH}$ was examined with the $\mathrm{pH}$ from 7.0 to 13.0 at $40^{\circ} \mathrm{C}$. The protease showed high activity in a broad $\mathrm{pH}$ range of 8.0-11.0 and the optimal pH was about 10.0 (Figure 4(a)). The relative activity of the enzyme was $90 \%$ at $\mathrm{pH} 11.0$, and it was reduced rapidly when $\mathrm{pH}>11.0$. The relative activity of enzyme decreased to $45 \%$ and $10 \%$ at $\mathrm{pH} 12.0$ and 13.0 , respectively. These results showed that the enzyme was alkaline protease [31]. The range of $\mathrm{pH}$ is normal between 9.0 and 10.5 in detergents solution. The high enzyme activity in alkaline conditions is a significant element needed in nearly all detergent enzymes. These were also described by Li et al. [32], Hadj-Ali et al. [33], and Cheng et al. [34]. It proved that the enzyme produced by strain SD11 might be useful in the detergents solution. Meanwhile, the enzyme is more effective at alkaline environment compared to the detergent enzymes mainly used in the industry, such as Alcalase (Novozymes A/S) produced by B. Licheniformis which has a maximal enzyme activity at $\mathrm{pH}$ 8.0-9.0, and Savinase (Novozymes A/S) manufactured by $B$. clausii which has a largest activity at $\mathrm{pH} 8.0-10.0$ [35].

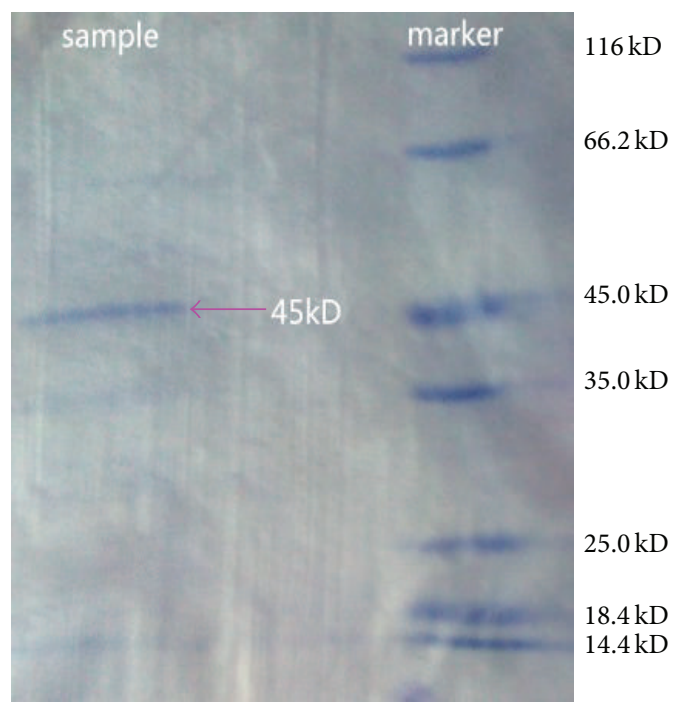

FIGURE 3: SDS-PAGE electrophoresis of the crude protease of strain SD11.

The stability of $\mathrm{pH}$ was measured after the enzyme was incubated in advance for $1 \mathrm{~h}$ in different $\mathrm{pH}$ buffers between 7.0 and 12.0 at $40^{\circ} \mathrm{C}$. Then the enzyme activity was examined at $40^{\circ} \mathrm{C}$ and $\mathrm{pH} 10.0$. The results were shown in Figure 4(b). The activity of the enzyme was very stable when the $\mathrm{pH}$ was between 7.0 and 11.0 (>80\%). However, the activity of enzyme reduced rapidly at $\mathrm{pH} 12.0$ (45\%). These results indicate the enzyme is suitable for potential industrial applications (e.g., protease in detergent), which requests broad $\mathrm{pH}$ (9.0-11.0) stability $[36,37]$.

3.4. Effect of Activity and Stability of the Crude Alkaline Protease by Temperature. The effect of the crude protease activity by temperature was investigated. The results showed that the crude alkaline protease from the strain SD11 was active from 30 to $70^{\circ} \mathrm{C}$ with an optimal temperature at $60^{\circ} \mathrm{C}$ (Figure $5(\mathrm{a})$ ). The relative activities of protease were about $\sim 97 \%$ and $\sim 100 \%$ at 50 and $60^{\circ} \mathrm{C}$, respectively. The optimal temperature of the protease was $60^{\circ} \mathrm{C}$ which had been reported from B. cereus BG1 [38], B. pumilus [39], and $B$. mojavensis [35].

The thermostability investigations of the crude protease indicated that the protease was absolutely stable within temperatures $50^{\circ} \mathrm{C}$ after $1 \mathrm{~h}$ incubation. The enzyme remained fully active after $1 \mathrm{~h}$ incubation at $40^{\circ} \mathrm{C}$. Even at 60 and $70^{\circ} \mathrm{C}$, the residual protease activity was 60 and $45 \%$, respectively, 


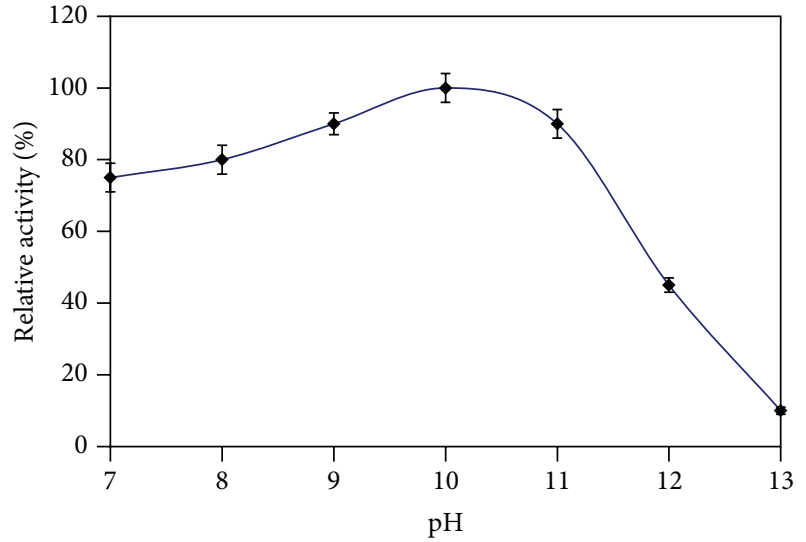

(a)

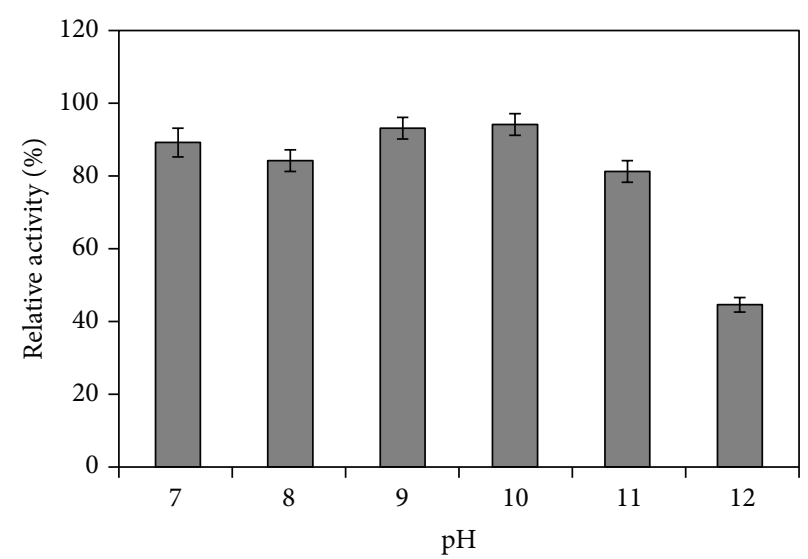

(b)

FIGURE 4: The effect of protease activity (a) and stability (b) by pH from strain SD11. (a) The enzyme activity was tested in different pH buffer solutions at $40^{\circ} \mathrm{C}$. The enzyme activity was maximum at $\mathrm{pH} 10.0$ regarded as $100 \%$. (b) The protease stability against $\mathrm{pH}$ was examined after the enzyme was incubated in advance in different $\mathrm{pH}$ buffer solutions for $1 \mathrm{~h}$ at $40^{\circ} \mathrm{C}$. The residual enzyme activity was tested at $40^{\circ} \mathrm{C}$ and $\mathrm{pH}$ 10.0. The enzyme activity without incubating was regarded as $100 \%$. Each point indicates the average value of three times, and error bars show standard deviation.

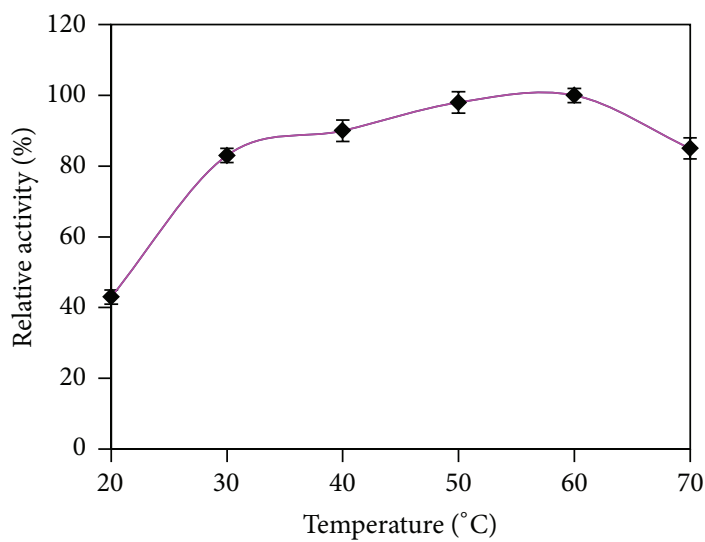

(a)

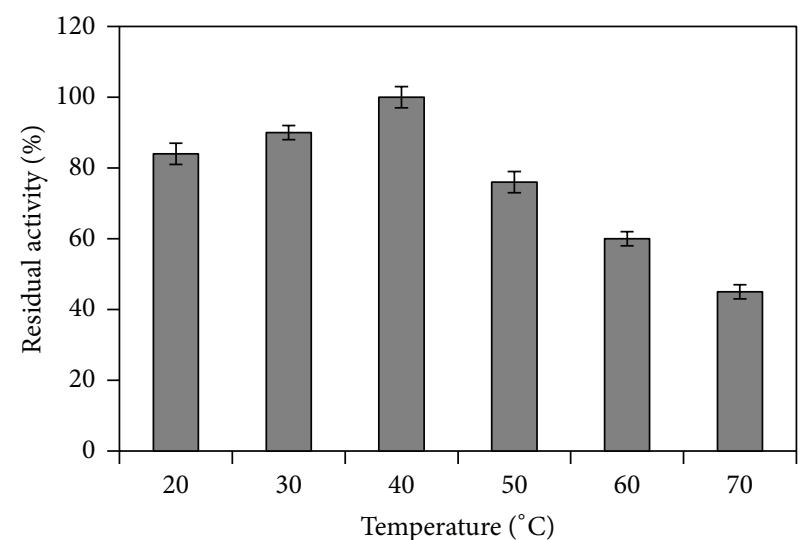

(b)

FIGURE 5: Effect of the activity (a) and stability (b) of the crude protease by temperature from strains SD11. (a) The activity of the enzyme was tested at various temperatures $\left(20-70^{\circ} \mathrm{C}\right.$ ). The enzyme activity was maximum at $60^{\circ} \mathrm{C}$ regarded as $100 \%$. (b) The protease stability against temperature was examined after the crude enzyme was incubated under temperatures between 20 and $70^{\circ} \mathrm{C}$ for $1 \mathrm{~h}$. The residual activity was tested under the normal conditions. The enzyme activity without incubating was regarded as $100 \%$. Each point indicates the average value of three times, and error bars show standard deviation.

showing that the enzyme would be used under moderate heating conditions (Figure 5(b)). The thermostability of crude protease was higher than that of alkaline protease from B. licheniformis MP1 [40], in which the enzyme activity was retained fully even incubated for $2 \mathrm{~h}$ at $50^{\circ} \mathrm{C}$ but remained only 41 and $5 \%$ after being incubated for $1 \mathrm{~h}$ at $60^{\circ} \mathrm{C}$ and $20 \mathrm{~min}$ at $70^{\circ} \mathrm{C}$, respectively. This thermal stability would be a superiority of this enzyme application in the industry such as laundry detergent formulations [5].

\subsection{Effects of Crude Alkaline Protease Activity by Inhibitors} and Metal Ions. The influences of enzyme inhibitor and chelating agent on the enzyme activity were investigated. The results were summarized in Table 3 . As we have seen, the crude enzyme was absolutely restrained by PMSF (phenylmethylsulfonyl fluoride, $5 \mathrm{mM}$ ), the serine protease inhibitor, demonstrating that the crude enzyme from strain SD11 contained serine-proteases. However, a metalloprotease inhibitor (EDTA) did not inhibit the enzyme activity, indicating the absence of metalloprotease in strain SD11. In fact, the activity of the enzyme from strain SD11 was active to $107 \%$ when preincubated with $5 \mathrm{mM}$ EDTA. These findings are not in agreement with earlier publications in which the enzymatic activity was found slightly restrained by EDTA [40]. These results demonstrated that the crude protease would be useful as an abluent additive for there are always the chelating agents in most abluents. Chelating agents are used for the accelerant in the stain removal and water softeners [18]. 
TABLE 3: Influences of the activity of the crude protease by various metal ions and enzyme inhibitors.

\begin{tabular}{lccccccccc}
\hline Chemicals & None & PMSF & EDTA & $\mathrm{Ca}^{2+}$ & $\mathrm{Mn}^{2+}$ & $\mathrm{Zn}^{2+}$ & $\mathrm{Cu}^{2+}$ & $\mathrm{Na}^{+}$ & 5 \\
\hline Concentration (mM) & - & 5 & 5 & 5 & 5 & 5 & 5 & 5 \\
Activity (\%) & 100 & 0 & $107 \pm 3.3$ & $145 \pm 3.6$ & $142 \pm 3.1$ & $115 \pm 2.6$ & $119 \pm 2.3$ & $136 \pm 2.1$ & $133 \pm 2.9$ \\
\hline
\end{tabular}

The enzyme activity was tested under normal conditions after it was incubated in advance with various inhibitors for $20 \mathrm{~min}$ at $40^{\circ} \mathrm{C}$. The enzyme activity was regarded as $100 \%$ without incubating. The influence of enzyme activity by metal ions was measured by testing the enzyme activity with metal ions ( $5 \mathrm{mM})$. The enzyme activity was regarded as $100 \%$ without metal ions. The enzyme activities indicate the mean of three experiments.

TABLE 4: Influence of crude alkaline protease activity by organic solvents and surfactant.

\begin{tabular}{lcccccc}
\hline Additives & None & SDS & $\mathrm{H}_{2} \mathrm{O}_{2}$ & Methanol & Isopropanol & Acetone \\
\hline Concentration & - & $5 \mathrm{mM}$ & $1 \%(\mathrm{v} / \mathrm{v})$ & $25 \%(\mathrm{v} / \mathrm{v})$ & $25 \%(\mathrm{v} / \mathrm{v})$ & $25 \%(\mathrm{v} / \mathrm{v})$ \\
Relative activity $(\%)$ & 100 & $95 \pm 1.3$ & $87 \pm 1.1$ & $138 \pm 1.1$ & $101 \pm 1.6$ & $141 \pm 2.1$ \\
\hline
\end{tabular}

The enzyme activity was tested under normal conditions after crude enzyme was incubated in advance with various additives at $40^{\circ} \mathrm{C}$ and $\mathrm{pH} 10.0$ for $20 \mathrm{~min}$. The enzyme activity without incubating was regarded as $100 \%$. The protease activities indicate the mean of three experiments.

The influences of crude protease activity were also investigated at $40^{\circ} \mathrm{C}$ and $\mathrm{pH} 10.0$ by the addition of the metal ions $(5 \mathrm{mM})$ to the reaction system (Table 3$)$. The additive of $\mathrm{Zn}^{2+}, \mathrm{Ca}^{2+}, \mathrm{Cu}^{2+}, \mathrm{Mn}^{2+}, \mathrm{Na}^{+}$, and $\mathrm{K}^{+}$increased the enzyme activity by $145,142,115,119,136$, and $133 \%$ of the control, respectively.

3.6. Effect of Crude Alkaline Protease Activity by Organic Solvents and Surfactant. In order to enhance the washing performance, a good protease used in detergent must be effective during washing and be stable and compatible with common detergent components such as oxidizing agents, surfactants, and other additions [4]. The crude protease from strain SD11 was preincubated at $40^{\circ} \mathrm{C}$ for 20 min existing with SDS and $\mathrm{H}_{2} \mathrm{O}_{2}$, and the residual enzyme activity was determined at $40^{\circ} \mathrm{C}$ and $\mathrm{pH} 10.0$ (Table 4). The enzyme was found to be very stable with the SDS at $5 \mathrm{mM}$, a strong anionic surfactant. This is not in agreement with the report from Hadj-Ali et al. [33], at which inhibition of enzyme activity with SDS was a common characteristic of serine-proteases. Oxidizing agents $\mathrm{H}_{2} \mathrm{O}_{2}$ at $1 \%(\mathrm{v} / \mathrm{v})$ caused a moderate inhibition $13 \%$. The present crude enzyme from strain SD11 seems very stable when these detergent additives were present.

Enzymatic synthesis of peptides has attracted great attention due to the numerous advantages of ester and peptide synthesis [41]. Proteases could be used for ester synthesis if they were stable with organic solvents $[20,42]$. The influences of enzyme activity by different water-miscible organic solvents were measured at $25 \%$ final concentration at $40^{\circ} \mathrm{C}$ and $\mathrm{pH}$ 10.0. As shown in Table 4, the crude enzyme activity was enhanced significantly by methanol and acetone in the reaction system. The relative activities were $\sim 138 \%$ and $\sim 141 \%$ with methanol and acetone, respectively, while the activity of the crude enzyme was almost not affected by isopropanol. It can be concluded that the enzyme produced by strain SD11 is highly stable in different organic solvents.

\section{Conclusions}

In the paper, we reported the screening of strain SD11 producing alkaline protease. The characterizations of the crude alkaline protease from strain SD11 were also reported. The crude enzyme contained serine protease and had no metalloprotease. The crude protease had optimal activity at $\mathrm{pH} 10.0$ and a broad range of $\mathrm{pH}$ stability (7.0-11.0). Furthermore, the protease was stable and active over a broad range of temperatures, had an optimum activity at $60^{\circ} \mathrm{C}$, and was also stable until $60^{\circ} \mathrm{C}$. The crude protease activity was improved by the addition of various $5 \mathrm{mM}$ solutions of $\mathrm{Ca}^{2+}, \mathrm{Mn}^{2+}, \mathrm{Zn}^{2+}, \mathrm{Cu}^{2+}, \mathrm{Na}^{+}$, and $\mathrm{K}^{+}$. The enzyme also could tolerate and be stable against oxidizing agent $\mathrm{H}_{2} \mathrm{O}_{2}$, anionic surfactant SDS, and organic solvents. These characteristics suggested that this enzyme would be suitable for industrial applications such as the synthesis of peptides and detergent formulations. It also could be used in the processes performed at wide ranges of temperatures and in alkaline environments. In future work, we will further investigate the purification, 3D structure determination, and structure-function relationship through site-directed mutagenesis of the protease from strains SD11.

\section{Conflict of Interests}

The authors declare that they have no direct financial relation with the commercial identities mentioned in this paper that might lead to a conflict of interests for any of them.

\section{Acknowledgments}

The authors are very thankful for the Hebei Province natural Science Foundation of China (D2010001149, D2014203102) and Ministry of Education by the Specialized Research Fund for the Doctoral program of Higher Education (20131333120010). Liping Wang is supported by NHMRC Postgraduate Scholarship Grant (1094606). 


\section{References}

[1] M. B. Rao, A. M. Tanksale, M. S. Ghatge, and V. V. Deshpande, "Molecular and biotechnological aspects of microbial proteases," Microbiology and Molecular Biology Reviews, vol. 62, no. 3, pp. 597-635, 1998.

[2] O. Kirk, T. V. Borchert, and C. C. Fuglsang, "Industrial enzyme applications," Current Opinion in Biotechnology, vol. 13, no. 4, pp. 345-351, 2002.

[3] V. J. Mehta, J. T. Thumar, and S. P. Singh, "Production of alkaline protease from an alkaliphilic actinomycete," Bioresource Technology, vol. 97, no. 14, pp. 1650-1654, 2006.

[4] C. G. Kumar and H. Takagi, "Microbial alkaline proteases: from a bioindustrial viewpoint," Biotechnology Advances, vol. 17, no. 7, pp. 561-594, 1999.

[5] R. Gupta, Q. K. Beg, and P. Lorenz, "Bacterial alkaline proteases: molecular approaches and industrial applications," Applied Microbiology and Biotechnology, vol. 59, no. 1, pp. 15-32, 2002.

[6] P. Kamath, V. M. Subrahmanyam, J. Venkata-Rao, and P. Vasantha-Raj, "Optimization of cultural conditions for protease production by a fungal species," Indian Journal of Pharmaceutical Sciences, vol. 72, no. 2, pp. 161-166, 2010.

[7] C. Sandhya, A. Sumantha, G. Szakacs, and A. Pandey, "Comparative evaluation of neutral protease production by Aspergillus oryzae in submerged and solid-state fermentation," Process Biochemistry, vol. 40, no. 8, pp. 2689-2694, 2005.

[8] S. K. Singh, V. R. Tripathi, R. K. Jain, S. Vikram, and S. K. Garg, "An antibiotic, heavy metal resistant and halotolerant Bacillus cereus SIU1 and its thermoalkaline protease," Microbial Cell Factories, vol. 9, article 59, 7 pages, 2010.

[9] O.-H. Ban, S.-S. Han, and Y. N. Lee, "Identification of a potent protease-producing bacterial isolate, Bacillus amyloliquefaciens CMB01," Annals of Microbiology, vol. 53, no. 1, pp. 95-103, 2003.

[10] R. N. Z. R. A. Rahman, M. Basri, and A. B. Salleh, "Thermostable alkaline protease from Bacillus stearothermophilus F1; nutritional factors affecting protease production," Annals of Microbiology, vol. 53, no. 2, pp. 199-210, 2003.

[11] R. Gupta, K. Gupta, R. K. Saxena, and S. Khan, "Bleach-stable, alkaline protease from Bacillus sp." Biotechnology Letters, vol. 21, no. 2, pp. 135-138, 1999.

[12] K. Jellouli, A. Bougatef, L. Manni, R. Agrebi, R. Siala, and I. Younes, "Molecular and biochemical characterization of an extracellular serine-protease from Vibrio metschnikovii J1," Journal of Industrial Microbiology \& Biotechnology, vol. 36, no. 7, pp. 939-948, 2009.

[13] A. Ventosa, Halophilic Microorganisms, Springer, Berlin, Germany, 2004.

[14] M. A. Amoozegar, A. Z. Fatemi, H. R. Karbalaei-Heidari, and M. R. Razavi, "Production of an extracellular alkaline metalloprotease from a newly isolated, moderately halophile, Salinivibrio sp. strain AF-2004," Microbiological Research, vol. 162, no. 4, pp. 369-377, 2007.

[15] C. Sánchez-Porro, E. Mellado, C. Bertoldo, G. Antranikian, and A. Ventosa, "Screening and characterization of the protease CP1 produced by the moderately halophilic bacterium Pseudoalteromonas sp. strain CP76," Extremophiles, vol. 7, no. 3, pp. 221228, 2003.

[16] C. G. Kumar, H.-S. Joo, Y.-M. Koo, S. R. Paik, and C.-S. Chang, "Thermostable alkaline protease from a novel marine haloalkalophilic Bacillus clausii isolate," World Journal of Microbiology and Biotechnology, vol. 20, no. 4, pp. 351-357, 2004.
[17] L. Lama, I. Romano, V. Calandrelli, B. Nicolaus, and A. Gambacorta, "Purification and characterization of a protease produced by an aerobic haloalkaliphilic species belonging to the Salinivibrio genus," Research in Microbiology, vol. 156, no. 4, pp. 478-484, 2005.

[18] A. Haddar, A. Sellami-Kamoun, N. Fakhfakh-Zouari, N. Hmidet, and M. Nasri, "Characterization of detergent stable and feather degrading serine proteases from Bacillus mojavensis A21," Biochemical Engineering Journal, vol. 51, no. 1-2, pp. 53-63, 2010.

[19] R. K. Patel, M. S. Dodia, R. H. Joshi, and S. P. Singh, "Purification and characterization of alkaline protease from a newly isolated haloalkaliphilic Bacillus sp," Process Biochemistry, vol. 41, no. 9, pp. 2002-2009, 2006.

[20] S. Ç. Aksoy, A. Uzel, and E. E. H. Kocabaş, "Extracellular serine proteases produced by Thermoactinomyces strains from hot springs and soils of West Anatolia," Annals of Microbiology, vol. 62, no. 2, pp. 483-492, 2012.

[21] R. K. Sarma, R. Debnath, R. Saikia, P. J. Handique, and T. C. Bora, "Phylogenetic analysis of alkaline proteinase producing fluorescent pseudomonads associated with green gram (Vigna radiata L.) rhizosphere," Folia Microbiologica, vol. 57, no. 2, pp. 129-137, 2012.

[22] C. Imada, "Enzyme inhibitors of marine microbial origin with pharmaceutical importance," Marine Biotechnology, vol. 6, no. 3, pp. 193-198, 2004.

[23] R. Salwan, A. Gulati, and R. C. Kasana, "Phylogenetic diversity of alkaline protease-producing psychrotrophic bacteria from glacier and cold environments of Lahaul and Spiti, India," Journal of Basic Microbiology, vol. 50, no. 2, pp. 150-159, 2010.

[24] B. K. Bajaj and P. Sharma, "An alkali-thermotolerant extracellular protease from a newly isolated Streptomyces sp. DP2," New Biotechnology, vol. 28, no. 6, pp. 725-732, 2011.

[25] U. K. Laemmli, "Cleavage of structural proteins during the assembly of the head of bacteriophage T4," Nature, vol. 227, no. 5259, pp. 680-685, 1970.

[26] M. Kunitz, "Crystalline soybean trypsin inhibitor. II. General properties," The Journal of General Physiology, vol. 30, no. 4, pp. 291-310, 1947.

[27] M. Cheng, S. Takenaka, S. Aoki, S. Murakami, and K. Aoki, "Purification and characterization of an eggshell membrane decomposing protease from Pseudomonas aeruginosa strain ME-4," Journal of Bioscience and Bioengineering, vol. 107, no. 4, pp. 373-378, 2009.

[28] M. M. Bradford, "A rapid and sensitive method for the quantitation of microgram quantities of protein utilizing the principle of protein dye binding," Analytical Biochemistry, vol. 72, no. 1-2, pp. 248-254, 1976.

[29] W. Zhu, D. Cha, G. Cheng, Q. Peng, and P. Shen, "Purification and characterization of a thermostable protease from a newly isolated Geobacillus sp. YMTC 1049," Enzyme and Microbial Technology, vol. 40, no. 6, pp. 1592-1597, 2007.

[30] L. E. Visôtto, M. G. A. Oliveira, A. O. B. Ribon, T. R. MaresGuia, and R. N. C. Guedes, "Characterization and identification of proteolytic bacteria from the gut of the Velvetbean caterpillar (Lepidoptera: Noctuidae)," Environmental Entomology, vol. 38, no. 4, pp. 1078-1085, 2009.

[31] A. Anwar and M. Saleemuddin, "Alkaline proteases: a review," Bioresource Technology, vol. 64, no. 3, pp. 175-183, 1998.

[32] S. Li, B. F. He, Z. Z. Bai, and P. K. Ouyang, "A novel organic solvent-stable alkaline protease from organic solvent-tolerant 
Bacillus licheniformis YP1A," Journal of Molecular Catalysis B: Enzymatic, vol. 56, no. 2-3, pp. 85-88, 2009.

[33] N. E. Hadj-Ali, R. Agrebi, B. Ghorbel-Frikha, A. SellamiKamoun, S. Kanoun, and M. Nasri, "Biochemical and molecular characterization of a detergent stable alkaline serine-protease from a newly isolated Bacillus licheniformis NH1," Enzyme and Microbial Technology, vol. 40, no. 4, pp. 515-523, 2007.

[34] K. Cheng, F.-P. Lu, M. Li, L.-L. Liu, and X.-M. Liang, "Purification and biochemical characterization of a serine alkaline protease TC4 from a new isolated Bacillus alcalophilus TCCC11004 in detergent formulations," African Journal of Biotechnology, vol. 9, no. 31, pp. 4942-4953, 2010.

[35] Q. K. Beg and R. Gupta, "Purification and characterization of an oxidation-stable, thiol-dependent serine alkaline protease from Bacillus mojavensis," Enzyme and Microbial Technology, vol. 32, no. 2, pp. 294-304, 2003.

[36] Y. C. Tsai, R. Y. Juang, S. F. Lin, S. W. Chen, M. Yamasaki, and G. Tamura, "Production and further characterization of an alkaline elastase produced by alkalophilic Bacillus strain Ya-B," Applied and Environmental Microbiology, vol. 54, pp. 3156-3161, 1988.

[37] B. Jaouadi, S. Ellouz-Chaabouni, M. Rhimi, and S. Bejar, "Biochemical and molecular characterization of a detergentstable serine alkaline protease from Bacillus pumilus CBS with high catalytic efficiency," Biochimie, vol. 90, pp. 1291-1305, 2008.

[38] B. Ghorbel-Frikha, A. Sellami-Kamoun, N. Fakhfakh, A. Haddar, L. Manni, and M. Nasri, "Production and purification of a calcium-dependent protease from Bacillus cereus BG1," Journal of Industrial Microbiology and Biotechnology, vol. 32, no. 5, pp. 186-194, 2005.

[39] C. G. Kumar, "Purification and characterization of a thermostable alkaline protease from alkalophilic Bacillus pumilus," Letters in Applied Microbiology, vol. 34, no. 1, pp. 13-17, 2002.

[40] M. N. Gupta and I. Roy, "Enzymes in organic media: forms, functions and applications," European Journal of Biochemistry, vol. 271, no. 13, pp. 2575-2583, 2004.

[41] K. Jellouli, O. Ghorbel-Bellaaj, H. B. Ayed, L. Manni, R. Agrebi, and M. Nasri, "Alkaline-protease from Bacillus licheniformis MP1: purification, characterization and potential application as a detergent additive and for shrimp waste deproteinization," Process Biochemistry, vol. 46, no. 6, pp. 1248-1256, 2011.

[42] D. Kumar and T. C. Bhalla, "Microbial proteases in peptide synthesis: approaches and applications," Applied Microbiology and Biotechnology, vol. 68, no. 6, pp. 726-736, 2005. 

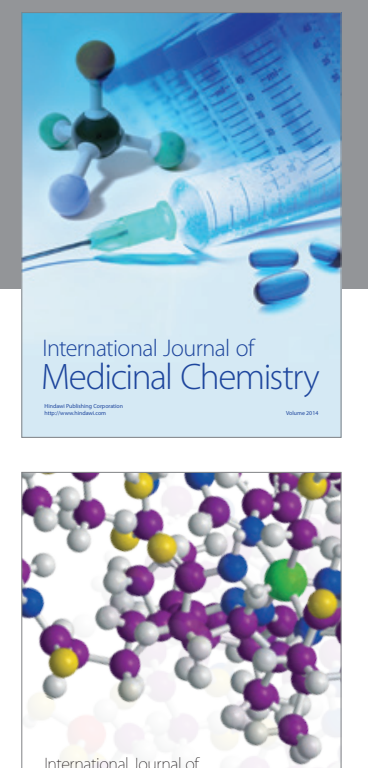

\section{Carbohydrate} Chemistry

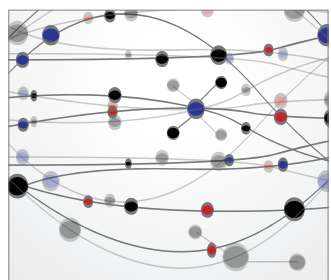

The Scientific World Journal
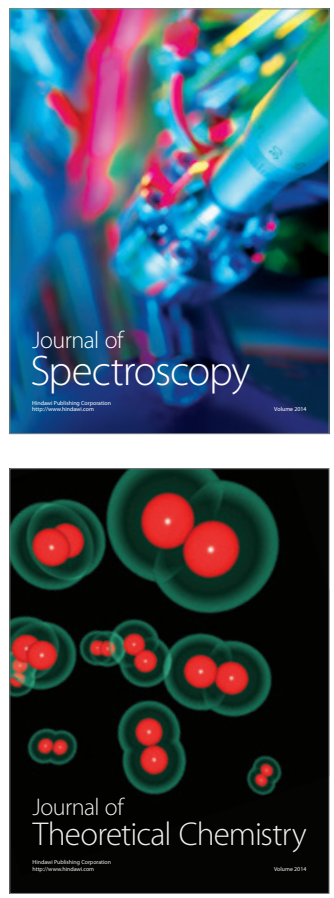
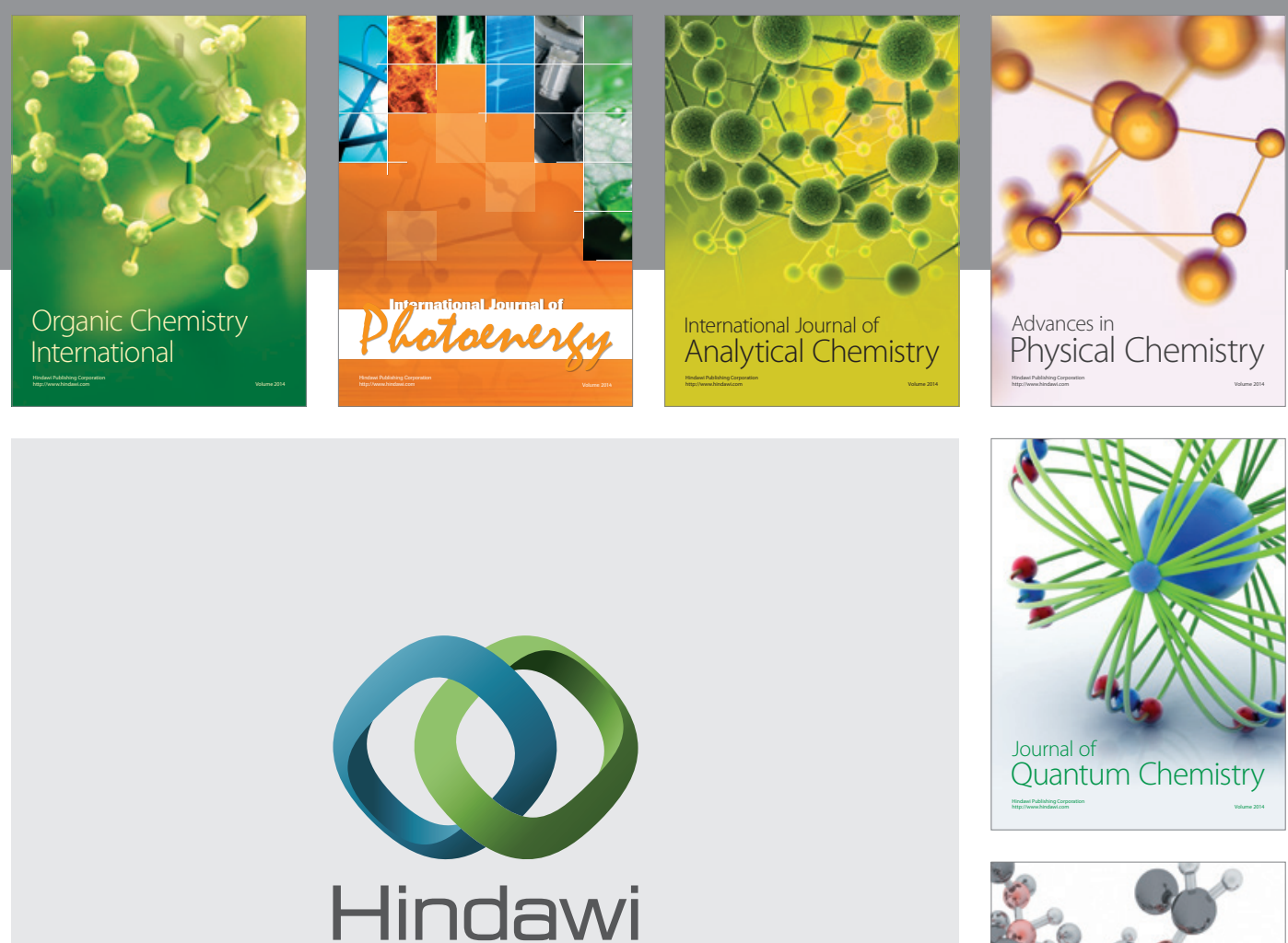

Submit your manuscripts at

http://www.hindawi.com

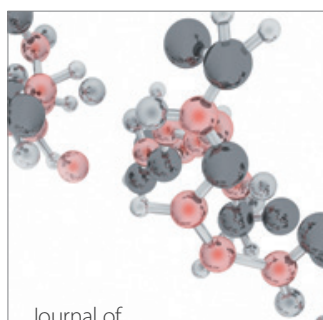

Analytical Methods

in Chemistry

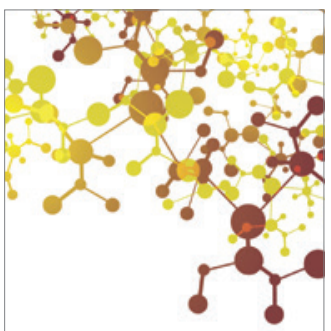

Journal of

Applied Chemistry

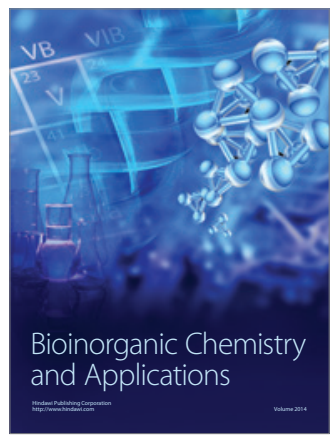

Inorganic Chemistry
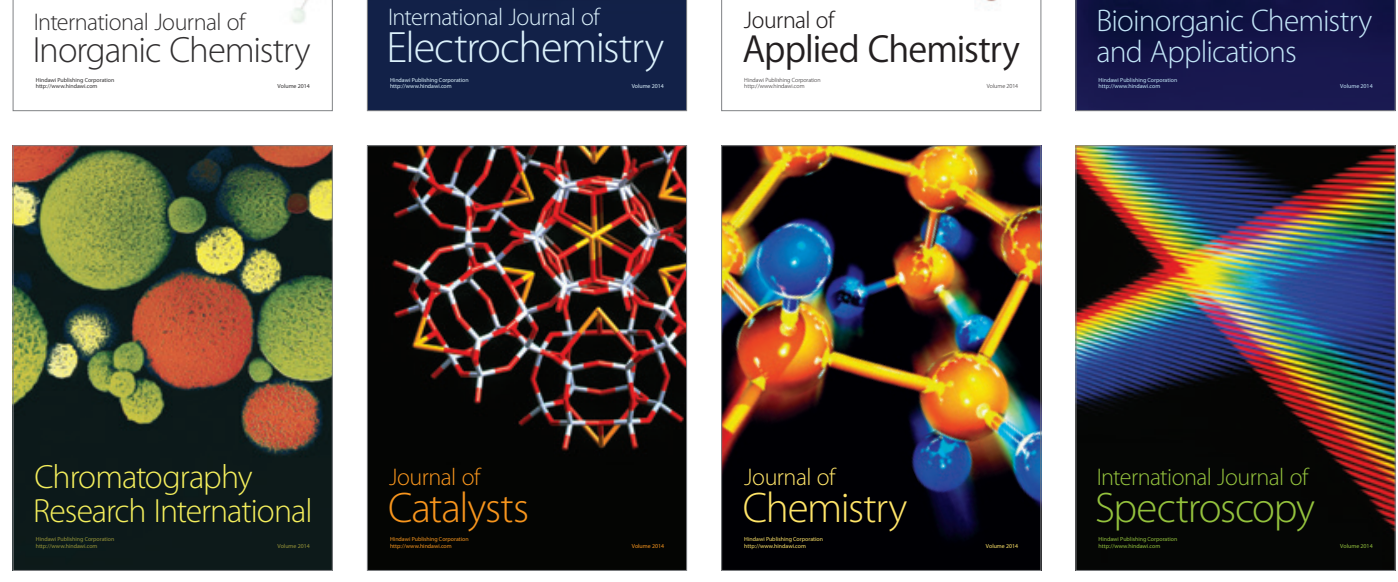